\title{
Xeroderma Pigmentosum: Exenteration of Palpebral Basocellular
}

\section{Carcinoma}

Tarik Bouzouba ${ }^{*}$, Bouchra Tamym, Imane Chabbar, Batal Elmarzouqi, Elhassan Abdallah, Amina Berraho

Ophtalmologie B, Hôpital Des Spécialités de Rabat, Morocco

DOI: $10.36347 /$ sjmcr.2020.v08i01.022

| Received: 08.01.2020 | Accepted: 15.01.2020 | Published: 26.01.2020

*Corresponding author: Tarik Bouzouba

Abstract

\section{Case Report}

Xeroderma Pigmentosum (XP) is a very rare genetic disease characterized by extreme sensitivity to the sun. We report a case showing a very bad evolution leading to palpebral exenteration in a 21 years old patient.

Keywords: Xeroderma Pigmentosum (XP), exenteration, Basocellular Carcinoma.

Copyright @ 2020: This is an open-access article distributed under the terms of the Creative Commons Attribution license which permits unrestricted use, distribution, and reproduction in any medium for non-commercial use (NonCommercial, or CC-BY-NC) provided the original author and source are credited.

\section{INTRODUCTION}

Xeroderma Pigmentosum (XP) is a very rare genetic disease characterized by extreme sensitivity to the sun and UV1 rays. If they are not completely protected from sunlight, patients suffer accelerated aging of the skin and inevitably develop damage to the eyes and skin which can lead to multiple cancers.

\section{Clinical Case}

We report a 21-years-old Moroccan male case from a first-degree inbred marriage followed for xeroderma pigmentosum, presents a lesion suspected of malignancy in the external canthus and lower eyelid of the left eye (Figure-1), thickening of the eyelid at palpation and infiltrated aspect of the bulbar conjunctiva.

\section{RESULTS}

A biopsy is indicated showing a nodular type of basocellular carcinoma. A CT scan shows regular thickening of the lower eyelid without mass syndrome (Figure-2). Given these clinical, biological and radiological data, an exenteration is indicated (Figure$3)$.

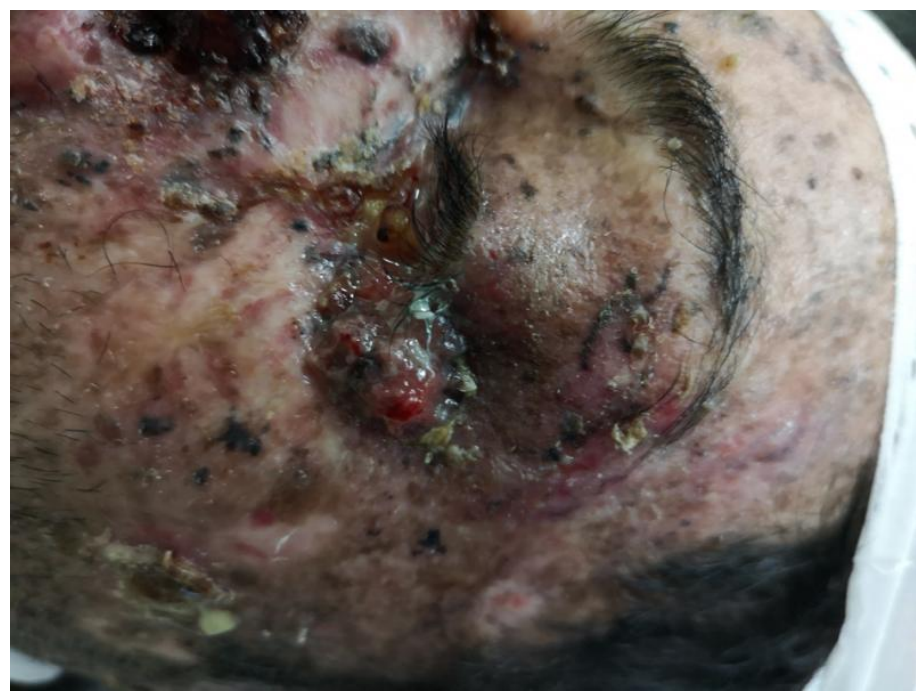

Fig-1: Basocellular carcinoma in the outer canthus and lower eyelid of the left eye 


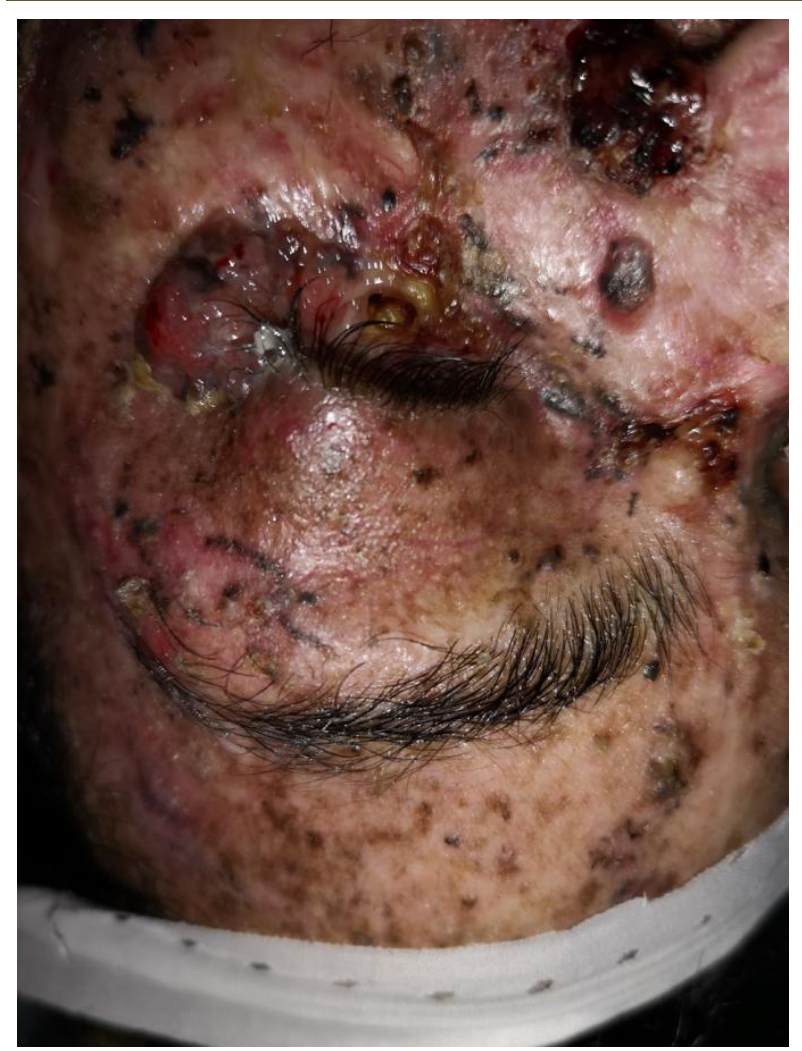

Fig-2: Basocellular carcinoma in the outer canthus and lower eyelid of the left eye

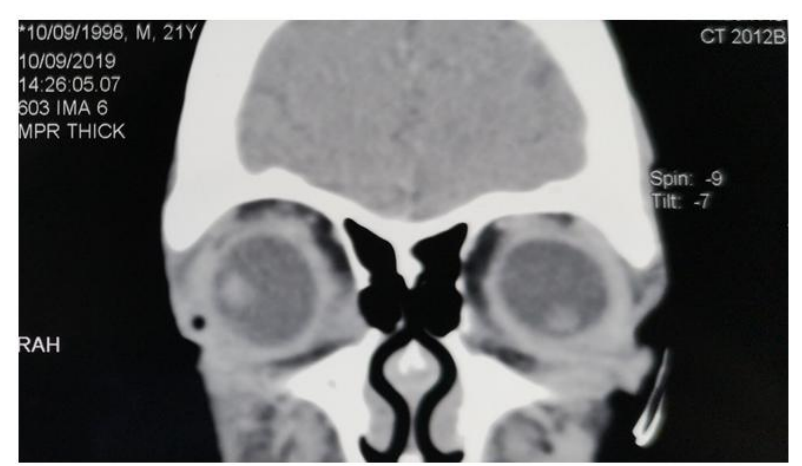

Fig-3: Regular thickening of the lower eyelid without mass syndrome on CT

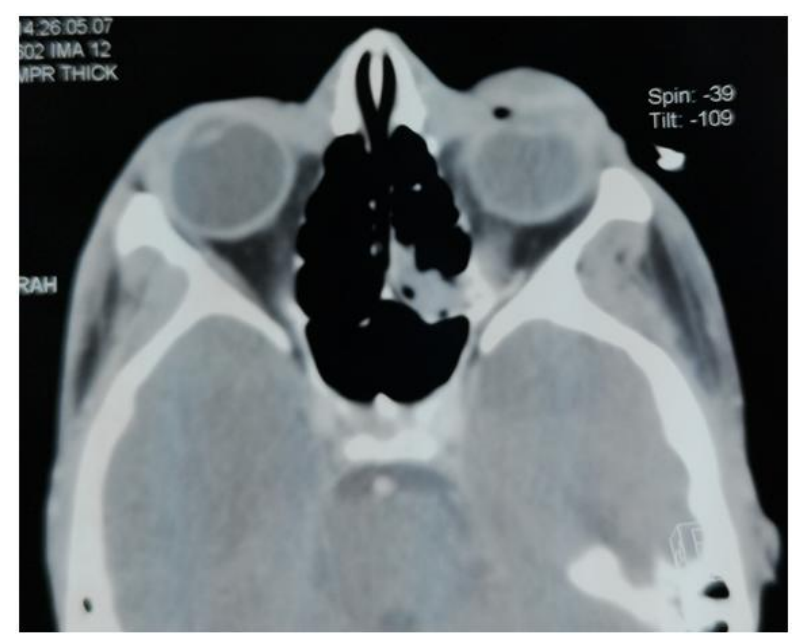

Fig-4: Regular thickening of the lower eyelid without mass syndrome on CT

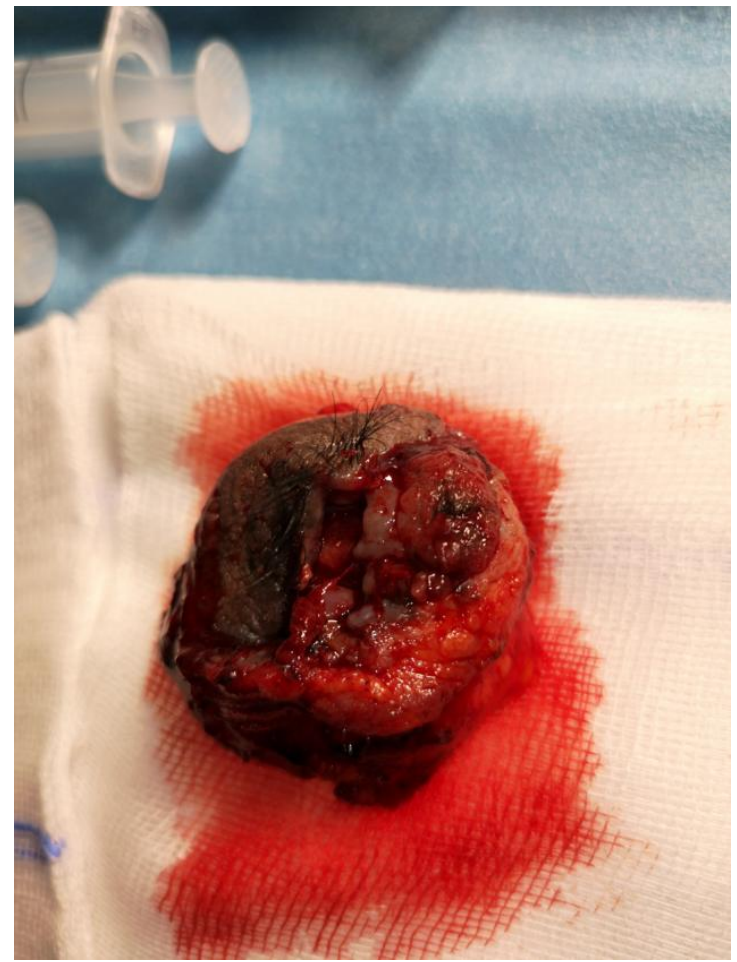

Fig-5: Post surgery image

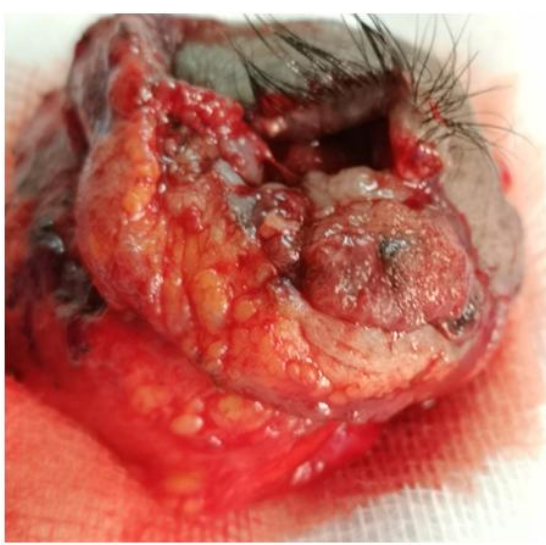

Fig-6: Post surgery image

\section{DISCUSSION}

Xeroderma pigmentosum (XP) is a rare inherited genetic disorder characterized by extreme sensitivity to ultraviolet light, inducing skin and eye damage and multiple skin cancers [1]. In the absence of curative treatment, management is essentially based on the prevention and detection of suspected lesions.

In the case of this patient, the notion of inbreeding, the residence in a sunny country and the lack of adequate and strict prevention measures are all factors contributing to this dramatic evolution.

\section{REFERENCES}

1. Magnaldo T, Sarasin A. Xeroderma pigmentosum: from symptoms and genetics to gene-based skin therapy. Cells tissues organs. 2004;177(3):189-98. 